ABORIGINAL HISTORY 1981 5:1
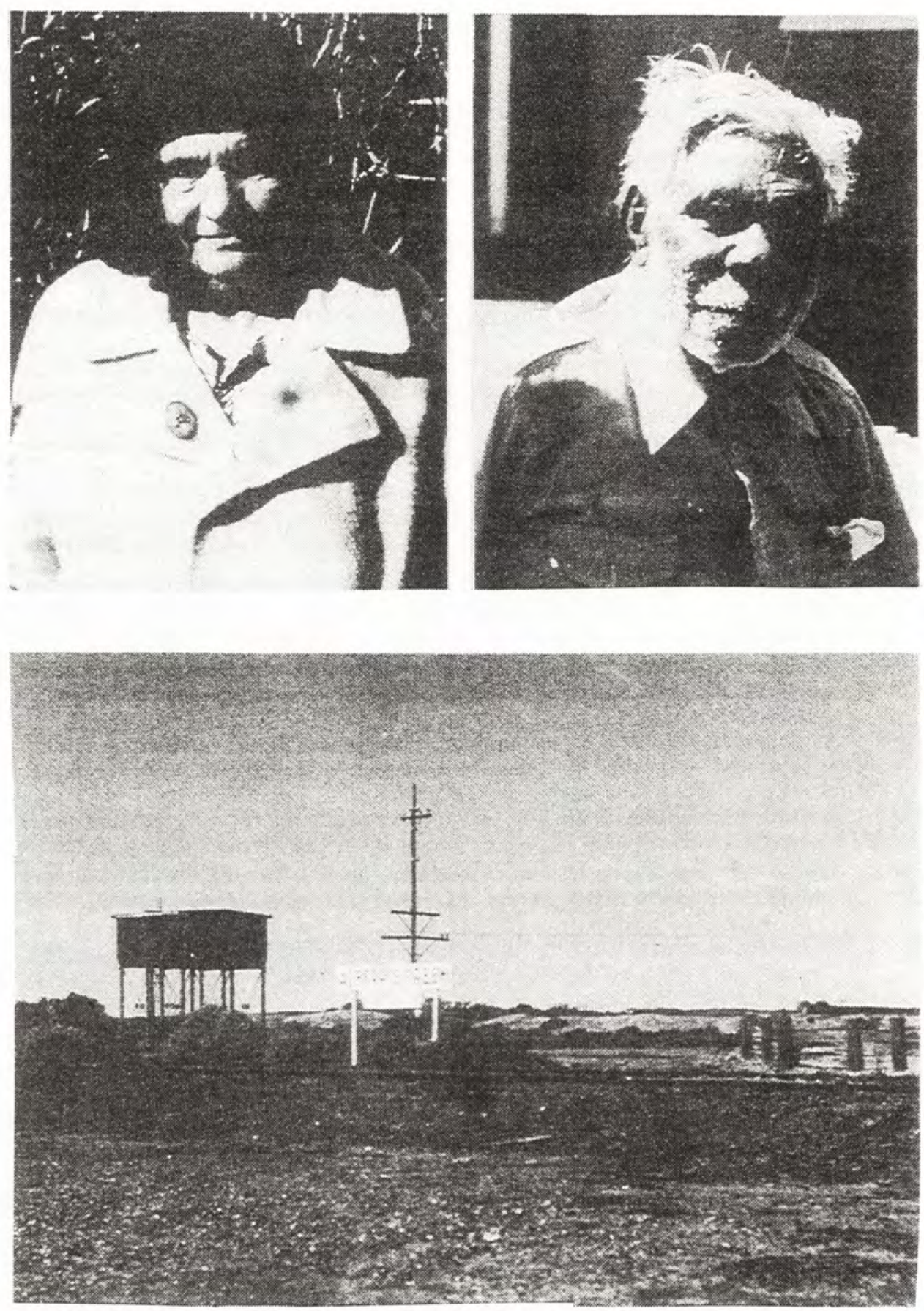

Top left: Mrs Mona Merrick, Port Augusta, July 1981.

Top right: Mr Johnny Reece.

Above: The tank at Alberrie Creek, July 1981.

Photographs by L.A. Hercus 


\title{
AFGHAN STORIES FROM THE NORTH-EAST OF SOUTH AUSTRALIA
}

\author{
Luise A. Hercus
}

The speakers of Arabana held the country to the west of Lake Eyre; the closely-related Wayganuru language was spoken in the Simpson Desert and on the lower Diamantina. The few remaining speakers of these languages nowadays live mainly in Marree and Port Augusta, South Australia. They remember many stories about the 'Afghan' camel-drivers who first entered their country in the nineteenth century. The men popularly known as Afghans were Urdu and Balochi speakers who came from what is now Pakistan, and were brought to Australia largely as a result of the activities of Sir Thomas Elder and the Beltana Pastoral Company. Drivers and camels arrived in large numbers - 124 camels were unloaded at Port Augusta in January 1866 - and had an early and particularly important impact on the arid areas of north-eastern South Australia. The Afghans and their camels provided the only efficient means of transport from Beltana and Marree to Alice Springs in Central Australia before the completion of the railway line. They also continued to provide transport for the pastoral stations along the Birdsville and Strzelecki tracks until the 1920s.

The history of the Afghans and their camels has been recounted many times and need not be reiterated here. ${ }^{1}$ But there are few published records of Aboriginal reaction to the presence of the Afghans. At first these strangers roused fear, but soon Aborigines were able to make shrewd judgments about the different customs of these outsiders. The Afghan predilection for plump, fairskinned women, the role of bride-price in their marriage arrangements, their burial practices, their food and butchering rituals, their jealous pride and fear of losing face, and their preoccupation with money were acutely observed and remembered by Aboriginal people, as these stories illustrate.

The Afghans, just like Europeans, were outsiders as far as Aboriginal society was concerned: Arabana people called them 'Abigana' or uadjbala madimadi 'white fellows with hair-string' or gadabu jara-nara 'head tied up', references to the turban that was invariably worn. The population of Marree was divided by the railway line; to the west lived the European Australians; to the east was Afghantown, with the Aborigines living on the outskirts. Yet the three groups knew a good deal about each other, and prominent individuals won respect from other townsfolk regardless of their ethnic identity. The stories recounted here reveal something of the relations between Europeans, Aborigines, Afghan camel-drivers and Syrian traders in the Marree district between the 1890 s and 1930 s.

The Afghans had come without women of their own and in the early days there was good reason to teach young Aboriginal girls to beware of them. Anyone noticing a few of the marriage advertisements in Indian newspapers will be familiar with the attitude that 'fair' is 'beautiful'. As typical South Asians

1. See Barker 1964, McKnight 1969. 
the Afghans also held this view and so they tried to marry Europeans or very light half caste girls, or the young daughters of other Afghans: for these they often had to pay large sums of money. Because European girls were scarce and part Afghan girls were even scarcer and expensive, the Afghans tended to pursue Aboriginal girls with strictly dishonorable intentions. Abigana-ru danilira 'the Afghans might eat you' parents warned, just to make the girls wary. This fear was increased because the Afghans were culturally conditioned to prefer girls with well-developed figures: in their northern Indian homeland thinness was regarded as a sign of poverty and low status. The first two stories, told by Mona Merrick, describe the sentiments of three Aboriginal girls in the mid1890 s who imagined that they were being eyed as tasty morsels. Both stories came from Mona's mother, a woman of Arabana descent who married $\mathrm{Mr}$ Warren, owner of Finniss Springs Station. Mona herself is still part-owner of the station.

The stories told by Mona Merrick and by her brother Arthur Warren are in Arabana, those told by Ben Murray and Johnny Reece are in Wanganuru. Both languages are very closely related, although there are differences in both grammar and vocabulary. These differences account for apparent inconsistencies: for example camel is gamulu in Arabana, but usually gamuli in Wanganuru; the suffix - na conveys the present tense in Wanganuru, but in Arabana it fulfils the function of an imperfect aspect marker. The texts are accompanied by an interlinear gloss, and an English translation follows. The translation is as close to the original as possible; when words or phrases must be inserted for clarity these are shown in brackets. The phonemes of Arabana-Wanganuru and the abbreviations used in the gloss are explained in appendices.

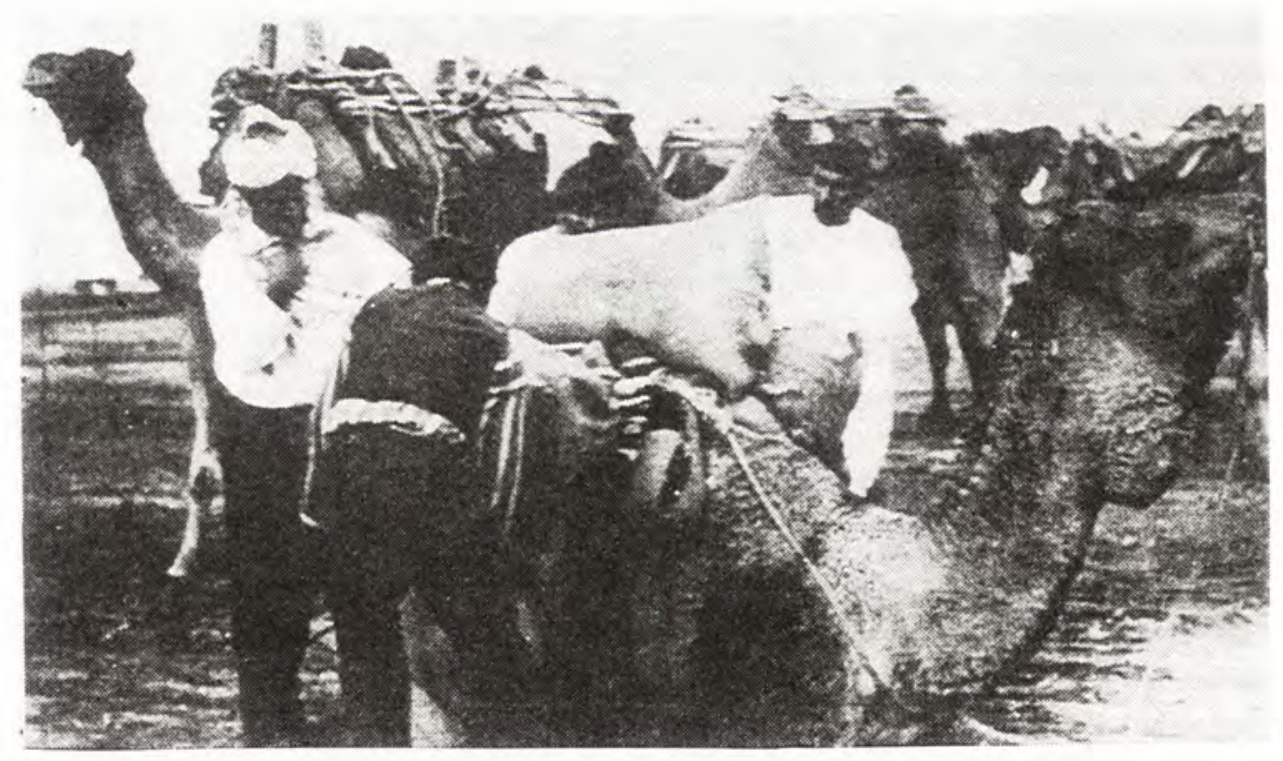

Loading Kidman's stores at Marree. 


\section{AFGHAN STORIES}

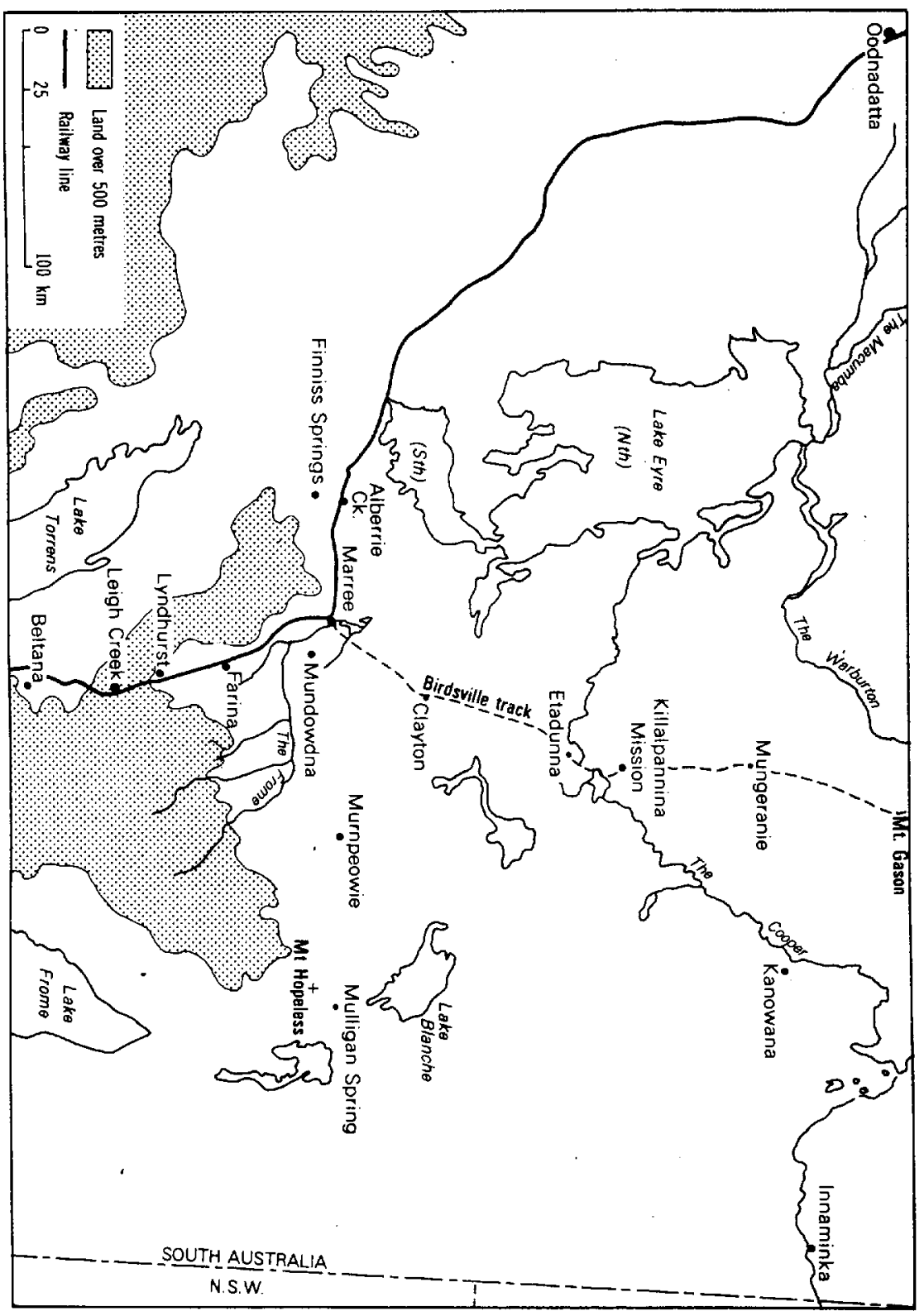

Places mentioned in 'Afghan' stories

Map drawn by Pam Millwood, Human Geography, A.N.U. 


\section{Getting a lift from Macumba}

The girl in this story had come from the Simpson desert not long before and was staying on Macumba, only twenty miles from Oodnadatta. She was glad of a lift to save her walking in the hot weather. She had become familiar with the practice of laying a freshly killed bullock on a bed of leaves, ready for butchering, but she was not familiar with the European and Afghan use of beds for what was done 'in the bush' in traditional Aboriginal society. ${ }^{2}$

1. Abigana-bula uljulu badja -nḍa-yanu gamulu bargulu-na

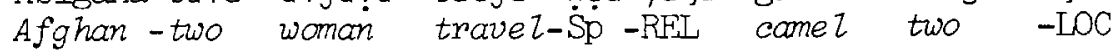

Magamba-ru, uga-ru dad -ma-nda Magamba. uljula bidla Macumba-ABI, he -ERG Zeave-Vb-PRES Macumba. woman nome

Barada.

Baraḋa.

2. gala -na guda mar̄a, guda gira-nda, guda banda

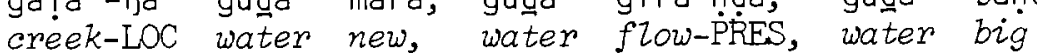

ganda-ga.

rain -PAST.

3. maga maba-nda, kerosene-tin banda gudni -nda

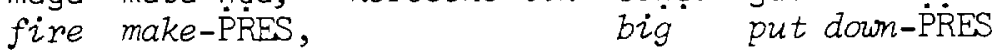

maga-na.

fire-LOC.

4. "maga mani-nda, maga bunda-da, njinda-dalba

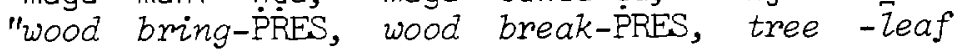

mani -nda gula mani-nda, gudliya manda!"

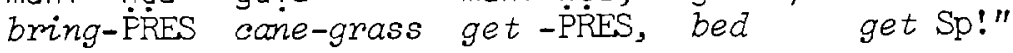

5. budluga gari-ri bida-ra, magidi mani-ra njinda

buzlock they-ERG kiiz-PUTC, gun take-PUNC. wood

mani-ligu mandara, bungudu, gudliya. ba!u-na

take-HIST wattze, cassiábush, bed. open-LOC

clean 'm njinda-na.

wood $-L O C$.

6. uljula njinda bunda-da mandara, Ilgiwara gala -nana woman wood break-PRES wattie, IZgiwara oreek-EL

uga nar̄a -na: "kerosene-tin banda, didi nuga;

she wormy-iMPERF: biğ, tea much;

budluga badni -na, ibi badni -na mina bula-ru bullock nothing-IOC, sheep nothing-IOC what two-ERG

2. White 1975 . 
ilana napu, ana-naru dañi-1i, ana daṇi-ligu thus how, me-first eat-FUT, me eat-PURP

waya-nḍa!"

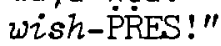

7. njinda bunda-da manda manda warida-gi warida wood break-PRES get Sp, get Sp far -EMVH far

diga -lugu ga!a-na njinda-na, maldja abira, njinda return-HIST creek-LOC tree -LOC, not gum, tree

alga nuru.

form other.

8. uga-ru nawi-ra madabuda yabmi-yabmi-nda, uga she-ERG hear-PUNC old man curse-curse-PंRES, she

darga-nda njinda-na -du, llgiwara ga!a -na guda -na, stand-PRES tree -LOC-EMPH, Ilgiwara creek-LOC water-LOC,

yada njinda nuru -na, duru darga-lugu.

further tree other-LOC, inside stand-HIST.

9. maldja yadla diga -lugu, maldja yada yuga-ga, not close return-H $\amalg S T$, not further go -PAST,

dad -ma-lugu diga -nda Magamba-rugu.

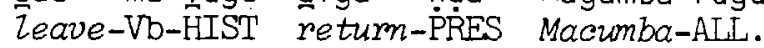

10. wadjbala -bula, Abigana-bula yabmi-yabmi-nda "bundju whitefellows-two, Afghon-two curse-curse-PंRES "meat

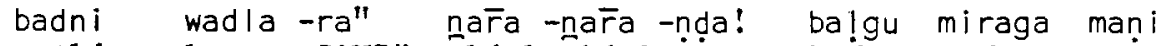

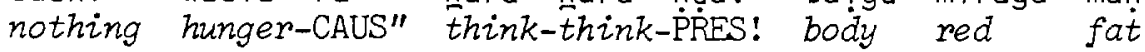

nuga ulju!a, anduna' Luga -ru nunda-ga.

much woman, my mother-ERG telz-PAST.

\section{Translation}

1) Two Afghans and a woman had been travelling (that day) with two camels from Macumba, she was leaving Macumba. Her name was Barada.

2) There was fresh water in the creek (where they were going to camp), the water was flowing strongly, big rain had fallen.

3) They (the Afghans) made a fire, and they put a big kerosene tin (full of water) on the fire.

4) (They said to her): 'Bring some sticks and break the sticks into little pieces, bring some foliage from the trees, get some cane-grass, make a bed!'

5) (She began to think): 'When they kill a bullock they get a gun and put down sticks, wattle and cassia shrub to make a bed. Out in the open, on the bed of sticks they clean out (the carcass)'.

6) The woman went on breaking up sticks of wood, wattle and shrubs from the side of the Ilgiwara creek. She began to get worried: 'That's a big kerosene tin and a lot of tea: since they haven't got a bullock, and since they 
haven't got a sheep, why are the two of them doing all this (getting a bed ready)? It's me they are going to eat; they want to eat me!'

7) She broke up sticks, picked them up and picked them up, further and further she went back (in the direction where Macumba was), right in the creek, amongst the trees - they weren't coolibah trees, but a completely different looking tree. ${ }^{3}$

8) She heard the two men swearing and cursing as she stood behind a tree, in the Ilgiwara creek, in the water. She (crept) further away to (stand behind) another tree, she stood (hidden) in the water.

9) She didn't go back near them, she didn't travel on - she got away and returned to Macumba.

10) She kept thinking: 'Those two whitefellows, those Afghans, are cursing and swearing because they haven't got any meat now, they are hungry!" She was a woman with brown skin (not jet black) and she had lots of fat on her. That's what my mother said.

\section{The train was late at Alberrie Creek}

Alberrie Creek is about 60 kilometres on the Oodnadatta side of Marree. There is a small building there, which used to house a railway gang, but there were no other habitations anywhere in the vicinity. In the daytime during the working week the place would have been deserted. Now of course, with the closure of the railway, the railway cottage is permanently uninhabited. Even before the Warrens took over Finniss Springs Station, to which this whole area belongs, Aborigines, mainly Guyani but also some Arabana, camped by some of the springs, some distance to the north and west, and the two girls has presumably been there visiting relatives.

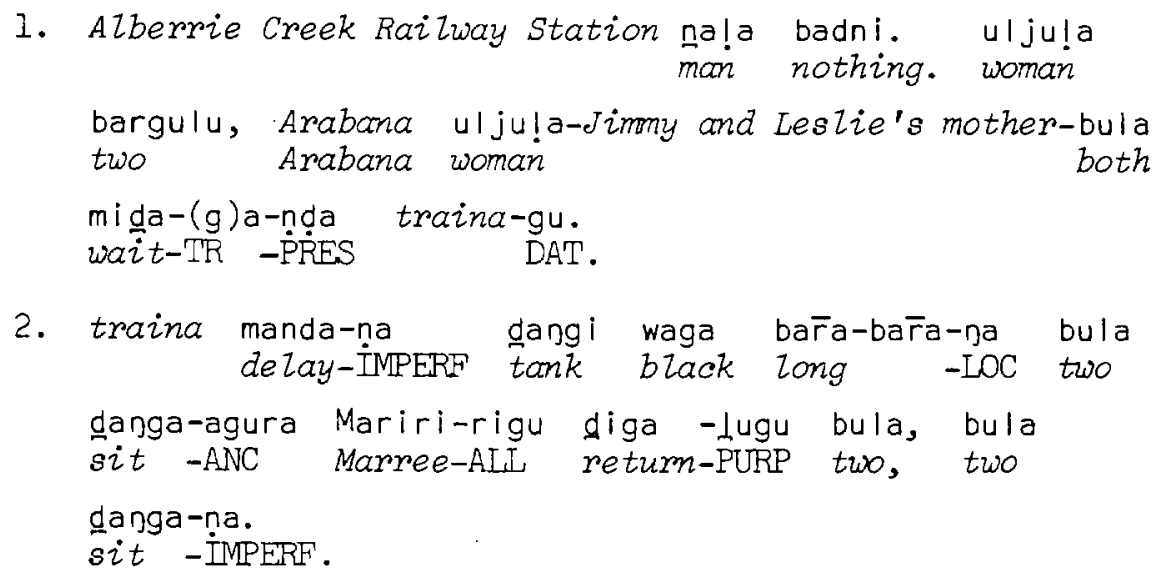

3. The 'different' tree, unknown in Arabana country, is Acacia cyperophylla, the Red Mulga, which grows along creek-beds from the Oodnadatta area northwards. Wangajuru people from the desert side of the Dalhousie area referred to the tree by its Aranda name abmuna. It is a slender tree with striking red bark and thin foliage. 


\section{AFGHAN STORIES}

3. Abigana-bula yuga-nda-na - damu-rugu gamulu-buru Afghan -Dl go -S $\dot{\mathrm{p}}$-IMPERF dam -ALL comel-having guda mani-1igu. bula yamba-a -1ugu-straightoway they water get-PURP. two ask -TEMP-H $\amalg S T$

asked! njiba nari -ma-nda, jama dargi-dargi, clothes fly up-Vb-PिES, breast display,

nama nani-na:

breast see -NP!

4. bula nama dargi -nḍa bula!

two breast display-PंRES two!

5. bula juma-nda, balgu miraga, maldja a!̣a waga, two like-PRES, flesh red, not true black,

bula mani-nuga.

two fat -much.

6. bula dadla-ra wa -nda, "mara maldja gudni-nda, two fear-CAUS want-PंRES, "hand not put -PंRES,

dani-ligu waya-nda! traina ungulu yuga-nda, eat -PURP want-PंRES! train when go -PंRES,

wadjbala -bula nama dargi-la -dira!

whitefelzow-two breast show -ALT-ACT PUNC:

7. "njiba gari-ma-nda, dara nani-na! show'm leg!

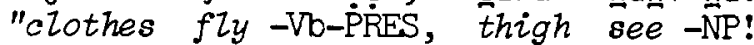

8. nama dargi-na dara darg'-argi-na, bula breast show -IMPERF,' thigh show -show-IMPERF, both darg'-arg -argi-na numa-nda. bula-guna traina show -show-show-IMPERF like-PंRES. two-POS train

galga-wa-1 -da!

hurry-TR-ALT-PRES!

9. bula darg'-argi-na, bula dadla-ra wa -nda: two show -show-IMPERF, two fear-CAUS want-PंRES:

"bula-ru mina-mina yamba-ya-1 ira?"

"two -ERG what-what ask -TR-POT?"

10. "maldja nama dimba -da nigi-bula, juma-nda,

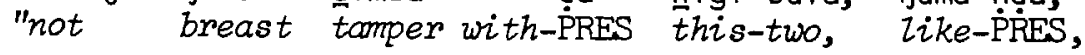
maldja mara yadla gunda, bula nani-nda -gi!" not hand elose put Sp, two Zook-PंRES-EMPH!"

11. mina-gu bula-ru nani-nda nama nari -ma-na-na, what-DAT two -ERG see-PंRES breast fly up-Vb-NP-IOC, 


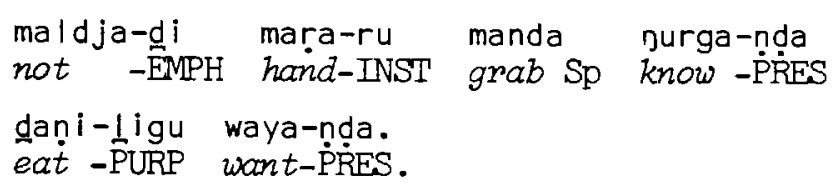

12. balgu nani-ligu nar̄i-ma-nana. njiba, bula-ru flesh see -PURP fly-VD-P IMPERF clothes, two-ERG $\begin{array}{llll}\text { jurga-nana } & \text { nigi-ri dani-1i -baru arimba-na, } \\ \text { know-P IMPERF } & \text { this-ERG eat -PTC-FUT we INCL-ÂCC, }\end{array}$ traina galga-nda yuga-nda!"

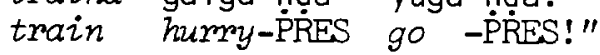

13. a!̣li yuga-nda traina! bula traina-ja wanga -da

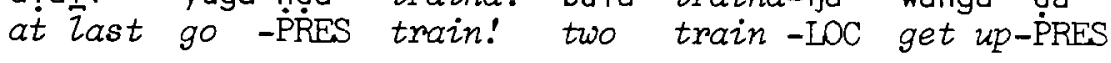
diga -lugu Mariri-rigu, Abigana-bula maldja waya-nda return-PURP Marree-AIL, Afghan -two not like-P̈RES traina, gamulu-na yuga-nda oodnadatta-rugu. train, camel-LOC go -Pं்ES Oodnadatta-AIL.

14. Abigana-bula maldja waya-nda train, they only wanted Afghan -two not like-PंRES girl-friend.

\section{Translation}

1) It was at Alberrie Creek Railway station - nobody was there; only two women, Arabana women, - Jimmy's mother and Leslie's mother-4 (they were just young girls then) - they were both waiting for the train.

2) The train was running late and so they sat down by that long black watertank, they were sitting there waiting to return to Marree.

3) Two Afghans came past with their camels on their way to the dam (which is near the tank) to get water. They asked - they asked straight away! 'Undo your clothes and show us your breasts - we want to see your breasts!"

4) The two of them showed their breasts.

5) The two Afghans liked what they saw: the girls had brownish-red bodies, not absolutely black, and they were both very plump.

6) The girls were frightened: 'they haven't touched us with their hands, they (just) want to eat us! When is this train coming - these whitefellows are making us show our breasts!'

7) 'Lift up your clothes so we can see your thighs - show'm leg!'

4. The reference is to two parallel cousins Jimmy and Leslie Russell; who have done much to help with work on both Arabana-Wanganuru and Diyari (Austin 1981, Hercus 1971, Donaldson 1979). Jimmy Russell Wanamiri 'Many Mornings' was born near Marree about 1897 and is now permanently at the Hawker hospital suffering from the effects of a stroke; Leslie Russell Wajabula 'Two Mornings' was born near Marree about 1903 and died in 1975. 
8) They went on showing their breasts, they showed and showed their thighs, oh how they went on showing and showing! If only their train hurried along!

9) They both went on showing, they were frightened: 'what will these two ask us next?'

10. 'They are not patting our breasts, these two, they are not even putting their hands anywhere near - they are just looking!'

11) 'Why do they keep looking at our breasts, while we've undone (our clothes) - they are not laying a hand on us: now we know they want to eat us'.

12) 'They made us undo our clothes so they could see our flesh'. They were quite sure now 'those two want to eat both of us, you and me! If only the train hurried and came!'

13. At last the train arrived. The two girls got on it to return to Marree. The two Afghans didn't want that train (to come). They went off with their camels to Oodnadatta.

14. The two Afghans didn't want that train (to come) - they only wanted a girlfriend.

\section{Reflections on a television program}

In late 1980 Mona Merrick saw a television program dealing with Afghan camel-drivers and the history of the Ghan railway line. It was one of the programs shown to mark the closure of the Ghan, and it caused her to reflect as follows:

Only praising old Afghan - no praise for Aborigine!

1. traina-na nawi-ga yani -mada -agura: Abigana-ru
LOC hear-PAST speak-RECIP-ANC:

gari-ri nunda-agura, Abigana ñigi waduwa -nda-agura,

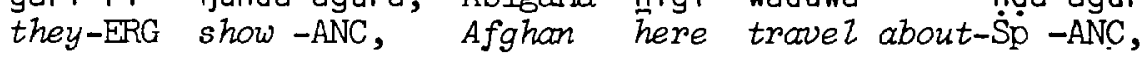

Birdsvilie way gari, yuga-ga Abigana-di, Abigana they go -PAST Afghan-EMPH, Afghan

gamulu-na yuga-nda!

came 2 -LOC go -PंRES:

2. maldja na!a gari-ri nunda-da adu nani-ga not Aborigine they-ERG show-PRES I ERG see-PAST

na!a warga-diya na!a yuga-nda, wargay1-nda

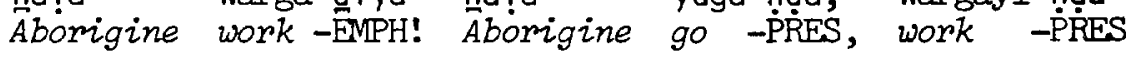
diga -nda gari, money nuga gari. return-PRES they, mich they.

3. This Hector Bossicot, his grandfather dandi mother's father-his $\begin{array}{lll}\text { gagaga nudi } & \text {-mara Willie gamulu-na } \\ \text { uncle } & \text { elder brother-having } & \text { camel -LOC }\end{array}$ wargayi-nda, gari yuga-nda wara -rugu? Finnissi-rigu work -PंRES, they go -PंRES where-ALL? ALL 


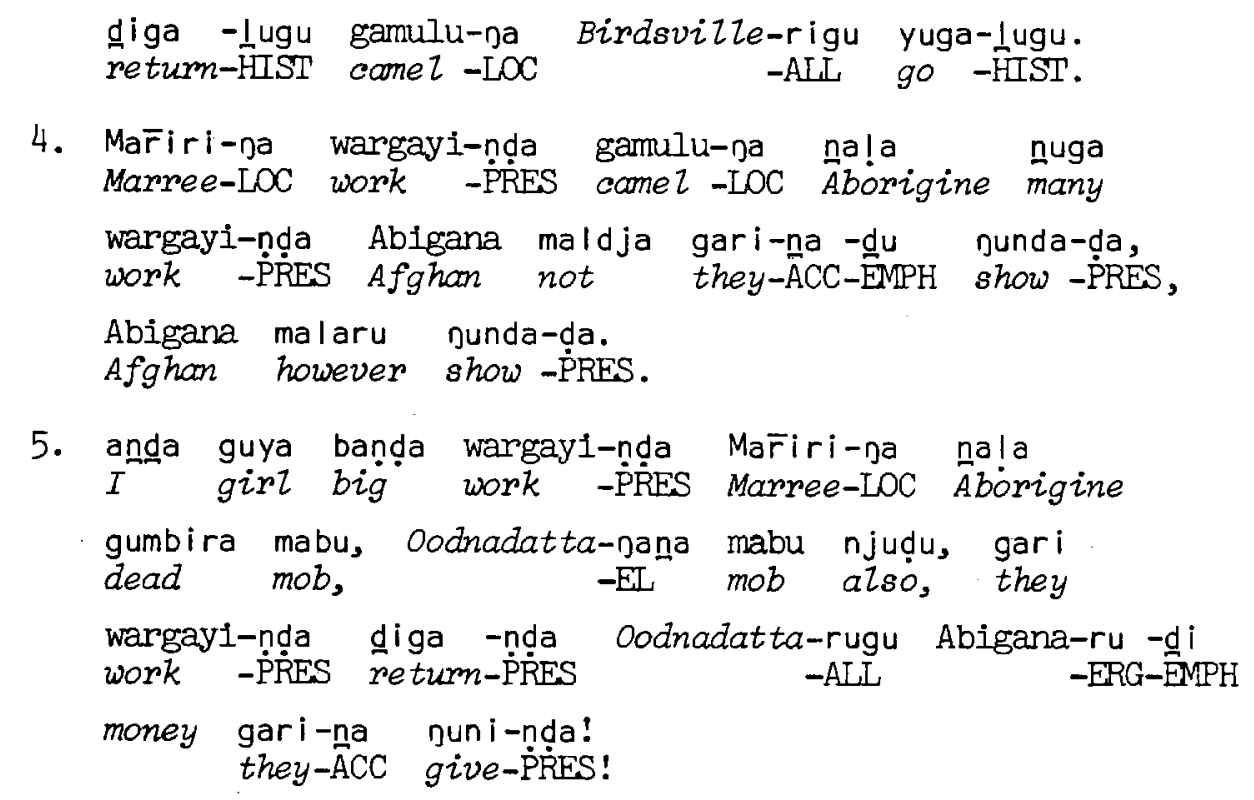

\section{Translation}

Only praising old Afghan, no praise for Aborigine.

1) I heard them talking to each other on that train (in the television program). They only showed (pictures of) Afghans: the Afghans used to travel here and there, the Afghans went on the Birdsville track, the Afghans went with their camels!

2) They didn't show any (pictures of) Aborigines. But I've seen Aborigines working (with camels), the Aborigines used to go off working and come back and get lots of money.

3) Hector Bossicot's maternal grandfather and his two uncles, (mother's brothers), they worked with camels, and they went all over the place, they came back to Finniss Springs and went off to Birdsville.

4) Many Aborigines from Marree worked with camels, as did the Afghans, but they never showed these Aborigines (in the film), only the Afghans.

5) When I was a big girl a lot of Aborigines from Marree were working (with camels), they are all dead now, just like those from Oodnadatta; they used to work (with camels) and then go back to Oodnadatta: the Afghans just paid them money (but stayed in town)!

\section{Sher Khan}

Ben Murray, himself of part-Afghan descent, has a vast store of knowledge regarding the history and oral traditions of the Lake Eyre basin. ${ }^{5}$ He related a number of stories connected with Afghans, some of which are given here. His main languages are Wanganuru and Diyari. The texts which follow are in Wayganuru. 
The Indian dowry system was never popular among Moslems: they tended to have a system of bride-price, but on a minor scale in the form of relatively small presents in money or kind given by the groom. The Afghans, however, were not lacking in business acumen and the great scarcity of eligible girls in the north of South Australia led to an escalation of price far beyond what would have been the norm in India.

1. Mūa, he bought that girl off Salim Khan for $£ 200$ !

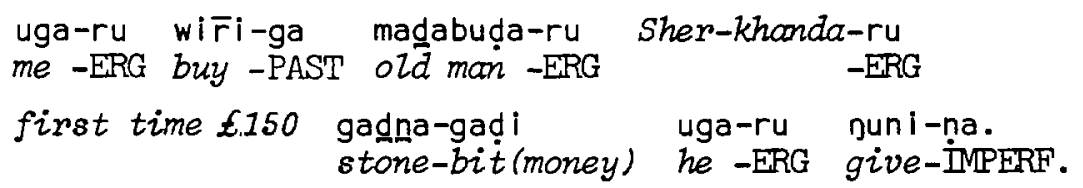

2. (Salim Khan said) "adu 'na Duni-ra." I ERG you ACC give-PUNC. 3. Mussā yuga-nda, uga-ru puni-ra $£ 200$, "aiz right"!
go -P̈RES, he -ERG give-PUNC,

4. nayi Sher Khon uga danga-nura gananaḍa Broken Hizl this he stay-CONT there

garu -ḍa diga -1 lugu.

there-EMPH return-HIST.

5. (Somebody told him) "That girl, old Khan's daughter, Mus $\bar{a}$ been buy'm for $£ 200$ !

(Sher Khan said): "Oh!"

6. uga yuga-nda traina-na; nari -di-ligu traina-na

he go -PRES -IOC; descend-ĪNC-HIST -LOC

Mus $\bar{a}-g i$-di! bula yadla widji-ligu. Sher Khan

-EMPH-EMPH! two close become-HIST,

mara bada-nda (and shot him).

hand hold-PंRES

7. garu -du uga diga -nda Irgaḍi-gaḍi-na

there-EMPH he go back-PRES Irgad̆i-gaḍina

towards Mundowdna garu didna-ra wadni -nda

there foot-CAUS follow-PंRES

ga!a -na, didna-walga-buru didna-ra.

creek-LOC, foot -shoe-having foot-CAUS.

8. Mus $\bar{a}$ they put'm in pub, no hospital those days,

purgu-ma-lugu minbaru uga-na nani-ligu yuga-nda:

good-Vb-PURP doctor he -ÂCC see-PURP go -ṔRES:

oh nara-nara nurgu awada nanga widji -na gaduru.

ah heart good that one alive become-IMPERF slowly. 


\section{ABORIGINAL HISTORY 1981 5:1}

9. yulja tracker didna-gari-li Jacky Nalbili-na policeman foot -see - $\mathrm{HAB}$ Nalbili-PROP

bula-ru wadni-nda ga!a-rugu yuga-nda, i! ina two -ERG follow-PंES creek-ALL go -PंRES, thus nani-ligu Mrondowdna siding yulja yani-nda see -ḦLST policeman speak-PंRES "I'll ring from here yulja $\begin{array}{cc}\text { Farina-nana, your bloke } \\ \text { policeman }\end{array}$ is stizl going that way."

10. "uga nudi -rigu-1" -gi." yulja diga -nda "he dead end-ALL-ENPH-EMPH policeman return-ṔRES Mā̄iri-rigu.

Maree -ALL.

11. Tracker carry on, uga didna-gari-1i. First double dam, he foot -see $-\overrightarrow{\mathrm{H}} \mathrm{AB}$

yuwu badni, yuga-lugu damu juru -rugu. yuwu gananada, man nothing, go -HIST d̄an other-ALL. man there, bambi-1i guda raizway pump - HAB water

12. (The tracker said) "Ah good day, see bloke come here?" "Yeah." "ah! diyarugu?" "awada." Farina yulja and "ah! where to?" "there." policeman

tracker bula darga-jura damu-ja. both stand-CONT dam-LOC.

13. "Ah, good day! Can you do something about my comezs? I come a long way, they get away!" "You came to my place, I give you tea, boil some egg for you."

14. uga-ru dada-ru boy "Help you look for comel!" Tracker he -ERG send-NAR

say "Ai boss you got the right one, that's him adu $I$ ERG

nurga-ra uga-na warada!"
know-PUNC he -ACC there!

15. digi -1igu. Give'm a feed first. "Take your boot off" take back-HIST.

didna 'guna widi-1i. "I know you!" "You know me, boss?" foot POS sore-EMPH.

"You're Sher Khan!" 
16. "I come back kill'm Müsā, kill'm woman too." il ina uga yanda "You might get ten or twenty years!" this he speak Sp.

17. djayila-na gudni-nḍa dada-ru uga-na goal -LOC put - $\dot{\mathrm{P}} \mathrm{R} E \mathrm{~S}$ send-NAR he -ÄCC

Westem Australia, warida. uga-guna time up, malga afar. he -POS not

purga-nda. He travel up and put a hat on, not like rag know - $\dot{\mathrm{P}} \mathrm{R} E S$.

they used to, ${ }^{6}$ diga -lugu uga Broken Hizr, bagu return-HIST he empty

danga-da, gaduru.

sit -PRES quiet.

18. Some say "why don't you go see that Mūsā?" "No, me finished!"

\section{Translation}

1) Mūsā, he bought that girl off Salim Khan for $£ 200 !^{6}$ But first Sher Khan bought her from the old man. He gave Salim Khan $£ 150$.

2) (Salim Khan said to him): 'I give her to you'.

3) Then Müsa came, and he gave Salim Khan $£ 200$ (and so Salim Khan said to him) 'all right (it's a deal)'.

4) Now Sher Khan was living in Broken Hill and he had gone back there.

5) (Somebody told him): 'That girl, old Khan's daughter, Mũsā been buy'm for $£ 200$ ! Sher Khan said 'Oh!'

6) He went to by train (to Marree), but Mūsă too had gone down to the train (he had heard that Sher Khan was likely to come and wanted to get away). The two came close to one another and Sher Khan moved his hand forward (and shot him).

7) He got away going along the Irgadi-gadina Creek towards Mundowdna (siding) there he walked along the creek-bed, although he had boots (he took them off and) he went barefoot.

8) As for Mūsā they put him in the pub to fix him up (there was no hospital in those days): a doctor came to have a look at him and he said: 'his heart is good and so he will slowly recuperate'.

9) That Marree policeman and his tracker, the one who looks at footprints, Jackie Yalbili (a Simpson desert Wayganuru) they both followed (Sher Khan) along the creek till they could see Mundowdna siding. Then the

6. This sum represented about 4 years wages for the average working man. 
policeman said 'I'll make a call from here to the Farina ${ }^{7}$ policeman, your bloke is still going that way'.

10) (The tracker said): 'Yes he'll finish up there (at Farina)'. The policeman returned to Marree.

11) The tracker went on, he was watching the tracks. At the first double dam (north of Farina) there was nobody. He went to the other dam (right next to the railway line). A man was there who had the job of pumping water for the railway.

12) (The tracker said): 'Ah, good day, see bloke come here?'

'Yeah' (said the railway man).

'Ah, where did he go to?'

'Just over there'.

The Farina policeman arrived and both he and the tracker stood by the dam (in front of Sher Khan).

13) (Sher Khan said) 'Ah, good day! Can you do something about my camels? I've come a long way, they got away from me!'

(The policeman said): 'You come to my place, I give you tea, boil some $\mathrm{egg}^{8}$ for you'.

14) (He signalled the tracker, pretending) to send him out: 'He'll help you look for the camels'.

The tracker said (secretly): 'Ai boss, you've got the right one, that's him all right, I know that's him just there'.

15) The policeman took Sher Khan back with him (to Farina). He gave him a meal first. Then he said 'take your boots off!' His feet were all blistered. 'I know you' (said the policeman).

'You know me boss?'

'You're Sher Khan' (said the policeman).

16) 'I come back kill'm Mūsā, kill'm woman too' - that's the sort of thing (Sher Khan) started saying.

'You might get ten or twenty years (in gaol)' (said the policeman).

17) He put Sher Khan in gaol and he was sent far away to Western Australia. When the time was up (for him to be released) he didn't want to think any more about it (about that matter of Mūsã and Salim Khan's daughter). He travelled up (from Western Australia) and he put a hat on, not a rag (turban) like the Afghans used to. ${ }^{9} \mathrm{He}$ went back to Broken Hill, and he stayed there, without doing anything further about it, he stayed there quietly.

7. Farina 'the great granny of the north' was apparently named facetiously (Fuller 1975:82), but at the turn of the century it was still a thriving small township serving the railway, trade, and the pastoral industry. A high proportion of the population was Afghan. It is now a ghost town and even the main road has been diverted away from it. For many years Ben Murray was the only inhabitant: he was quite happy because he could always 'jump on the rattler' and visit friends and relations at the only other settlements in the area, Marree $(60 \mathrm{~km})$, Lyndhurst $(30 \mathrm{~km}$ ) and even Port Augusta. But now (since November 1980) the 'Ghan' no longer passes through and Ben has moved to Marree.

8. The policeman was aware of the fact that Afghans would not eat meat offered to them because the beasts would not have been traditionally slaughtered.

9. Ceasing to wear a turban was a highly symbolic act by which Sher Khan broke away from his past life as an Afghan. 
18) Some people said to him: 'Why don't you go to see that Mūsā?' (But he answered) 'No, me finished'.

\section{'Azim Khan, 'Archie Kangaroo'}

The events related in this story took place around 1910-1912 when Ben Murray as a young man was working a camel train for the Lutheran mission at Killal pannina. When picking up loads at Marree he often called on 'Azim Khan, as did many other camel drivers. 'Azim Khan was in the employ of Abdul Qadir, who was the wealthiest of the Marree Afghans. Qadir had leased land in the area, and had planted date palms; he also kept goats.

1. Archie Kangaroo - he call himself that, he was really 'Azim

Khan. nuba-buru danga-ḍa. uga-ru madabuḍa-ru wife-hoving sit -PRES. he -ERG old man-ERG

loadaga wanba-da-ru Froma-rugu, mayuda wandi-nda carry-Sp-Nar ALL, master wait -REFL

warana-gu.

what -DAT.

2. Abigana juru from Broken Hill Wasim Khan uga Afghon other he

yuga-ñd'-inaru alada gamulu-ra.

go - $\dot{\mathrm{S}} \dot{\mathrm{p}}$-PLUP ready camel - CAUS.

3. uga-guna nonnygoata yagada-na danga-nura gananaḍa he -POS yard -IOC stay-CONT there

Mariri-na Abduz qadir down the bore-drain bida-lugu Marree-LOC kiiz-PURP

dan $\mathrm{i}-1$ i gu.

eat -PURP.

4. madabuḍa yuga-nḍa loada-buru, dadna-nḍa loading

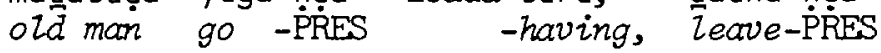

gananadia, where the bore-drain is, didna-ra -du

there,

foot -CAUS-ENPH

diga -ga to store gananaḍa diga - Lugu maḍi

return-PAST there return-FIST string

mani-ligu he was short of twine.

get -PURP

5. wanda-diga - Lugu, uga diga -jura nannygoata run -return-HIST, he return-CONT

gananada yuga-na thirty-two uga diga-ga

there go-INPERF he return

wand $\mathrm{i}-\mathrm{nda}-\mathrm{l}$ ugu-1 $-\mathrm{gi}$ !

wait -S $\dot{\mathrm{p}}-\overline{\mathrm{P} U R P}-\mathrm{ENPH}-\mathrm{ENPH}$ ! 

6. anda naridji-ya-nu anari gamulu-na, mission camel.

"ah, mayi diyara uga?" nuba uga-guna yani-nda, "oh, now then, where he?" wife he -POS say-PRES "ungulu wabayi-nda?" "He must have left early, he left "when finish-PंRES?"

a Zoad."

7. uga late diga -nda, djarda uga-guna gubmari-nuga. he retur-PRES, shirt he -POS blood-much.

"Oh, what's wrong with your shirt?" "I been kizling goat

down there, boss's place, kilz'm couple of goats,"

uga yani-nda.

he say-PRES.

8-9. (Told in English.)

10. "gudi-1igu garu -gu bangi-na gudni-ligu gumbira. "pulz-HIST there-ALL side -LOC put -HIST, dead.

ah diga -lugu garu." They might come with drag

on return-HIST there."

digi -la -gudi-ligu.

take back-ALT-puzz-PURP.

11. uga yanda: "ah yuga-nda nani-1igu! yambayi:

he say SP: "oh go -PंRES see -PURP! ask:

12-13. (Told in English.)

14. i! ina yanda, wa! u widji -na diga -nda thus speak SP, jealous become-PRES. I return-PंRES

Mission load mani-ligu, diga -nda Killalpannina, get -PURP, returm-P̈RS

malga yada nawi-ligu.

not more hear-HIST.

\section{Translation}

1) Archie Kangaroo, that's what he called himself - his name was really 'Azim Khan. He was a married man. One day he took a (camel) load out to the Frome (crossing) ${ }^{10}$ and waited there for his master Abdul Qadir for some reason or other.

10. The Frome crossing on the Birdsville track is only 6 kilometres from Marree - the bed of the Frome is the only area with small timber and bushes in an otherwise totally desolate landscape. There is always water about, on account of the bore. 
2) Another Afghan Wasim Khan from Broken Hill - he had gone there because he was ready to set off back home with his camels.

3) Abdul Qadir - he lived in Marree - he had goats ${ }^{11}$ there in a yard down by the bore-drain: they were kept there to be (ultimately) killed and eaten.

4. Wasim Khan went there (to the yard) with his load, he left his load there where the bore-drain is and went back on foot to the Marree store; he wanted to go and get some string because he was short of twine.

5) He came hurrying back to where the goats were, he almost got there on his way back, just to find a thirty-two (calibre rifle) waiting for him.

6) I came down this way (to Marree) with camels, mission camels. (I went to 'Azim Khan's place) 'Where is he right now?' I asked. '(I don't know) when he will finish work', his wife said. 'He must have finished early', I said, 'because he left his load at the Frome'.

7) He arrived late, with his shirt covered in blood. (I asked), 'Oh, what's wrong with your shirt?' 'I been killing goat there, down there, boss's place, kill'm couple of goats', he said.

8) A young bloke who had come from Broken Hill that morning he went straight there where his mate Wasim Khan had left his load. 'Afghan lying there on the other side of the road! It's him, my friend Wasim Khan'. He went back to Marree to tell the yulja (policeman). The yulja locked him up (in gaol as a suspect).

9) 'We'll get a tracker' (he said). 'We'll get Anada Johnny'. The tracker said: 'I seen'm track. I know this fellow, he's shepherd's goat for Quadir. He been here, this bush, shoot'em from here, thirty-two'.

10) 'He pulled'm from here to over there and put'm down, dead, by the side (of the road)'. 'They might come with a drag (i.e. a horse-drawn vehicle) to pull up and take back (the body)', the policeman said.

11) He (the policeman) said as he was going 'I'm going to see him ('Azim Khan)'. He asked:

12) 'Where are his clothes?' 'That's where he left'm, he left and I never watched! I did know there was something wrong - look more like human blood'. That's what I said.

13) He ('Azim Khan) was jealous. (When caught he said): 'Wasim Khan reckon he was going back to my place, but he never come near me, he went to the store, he had a set on me'.

14) That's what he said, he was jealous. ${ }^{12}$ I went to take the mission load, I went back to Killalpannina, and I never heard anything further.

11. The word 'nannygoat' is used as a general term for 'goat' in Aboriginal English: this change of meaning was brought about by the fact that only relatively few billygoats were kept.

12. 'Azim Khan felt that his hospitality was being slighted: being of lowly social standing (as an employee of Abdul Qadir) he was very sensitive. 


\section{The aged Afghan}

The events in this story took place around 1933-34 while Ben Murray was working on the vast and desolate Murnpeowie station which comprises the country immediately to the north and north-east of the Flinders Ranges: the ranges fall away suddenly to a treeless plain going down to Lake Blanche. Only small hills near the aptly named Mt Hopeless rise prominently out of the plain. Many Aborigines were employed on Murnpeowie including Mick McLean and Murtee Johnny. ${ }^{13}$ Ben Murray spent much of his time on the most remote parts of the station, checking the boundary fence. Mulligan Spring, where he came across the old Afghan, is not far from Mt Hopeless, and close to Lake Callabonna. The story is of particular interest as it shows the tenacity with which the older generation of Afghans adhered to their beliefs.

1. madabuda danga-libana Maṇbi -awi -na; mayi danda -du old̄ man stay-ANC Pigeon-water-LOC; then things-EMPH

gari-na warba-ru gamuli-ri igi -na Gudnanawa-na they-ACC carry-NAR comel-INST drive-PRES Kanowana-PROP,

igi -na Idniminga -rugu gamuli-na Gudnari-na dmive-PRES Innamincka-ALL camez-LOC Cooper-LOC

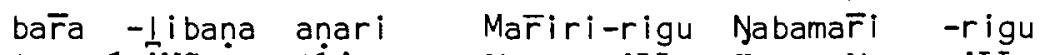
trave z-ANC this way Maree -ALL Nappa Merry-ALL

station Yawarawarga Yandruwanda-guna wadlu -na. Yawarawarga Yandruwanda-POS country-LOC.

2. You know them explorers Burke and them gananada wandja-ḍa there die -PRES

gari diga -ga malju-mayi badni -na -1 ' $-g i$

they return-PAST food nothing-LOC-EMPH-EMPH

gari-na igi -1i yuwu -ru mani-libaṇa, awaḍa they-ACC bring-HAB Aborigine-ERG get -ÂNC, there

gari wandja-na yadla. madabuda Abigana uriya. they die close. old man Afghan ancient.

3. uga gada -libana, malaru diga -na danga-lugu he travel-ĀNC, but return-PRES stay-T̈URP

Maṇbi -awi -na danga-da, gamuli uga-guna yuga-jug' Pigeon-water-LOC sit-PRES, camel he-POS go-HIST

ayi! madla-di -y -apu. Seven uga-guna gamuli. eh! bad -become-Gl-REL. he -POS camel.

4. mayi anda gananaḍa gada -nanga -da anda-du, then I there travel-CONT S-PRES I -EMPH, gaṇa-du malga-du wargạ̣i-na, uga danga-ḍa man -EMPH not -ENPH work -PRES, he sit -PRES

bagu $-11-g i$

empty-EMPH-EMPH.

13. See Hercus 1980. 


\section{AFGHAN STORIES}

5. uga diga -ga, nulba widji -ga uga madabuda he return-PAST, izz become-PAST he old man

Abigana, nuyu danga-da uga anda yuga-ga garu -guda Afghan, one stay-PRES he. I go -PAST there-ALL MuZZigan Spring Maṇbi -awi - pa.

Pigeon-water-LOC.

6. uga yuga-ga Maṇbi-rigu malju mayi mani-ligu, he go -PAST Pigeon-ALL, food get-PURP,

mayi gananaḍa diga -nḍa danga-lugu; anda yuga-ga then there return-PंRES stay-PURP; I go -PAST fence-ru uga-na nani-ligu.

-ABL he -ĀCC see -PिRP.

7. adu nani-ga warbi-nanga-nura, i lina yanda: "Oh me, IERG see-PAST lie -CONT S-CONT; thus speak:

I thought I'd die, got nothing to eat! Me sit down here."

8. danga-da uga cocky wandi-nda, "cocky come, me get'm sit -PRES he wait -REFL, gun, we want'm two, brother," bargulu big̣a-lugu, two hit -PURP,

wadn $i-1$ igu.

cook -PURP.

9. anda yani -nda: "ah ibi gari diga -nda I speak-PRES: "ah sheep they retum-PRES

Gunuwanda Springa-na ibi-ibi!" "Which way you come? -IOC sheep

Water in spring?" "I come from that way, guda bunda-garu! water drink-PLUP!

10. "Ah, me go!" anda yuga-nda, uga-inda wandi-wandi-nda I go - $\mathrm{P} \dot{\mathrm{RES}}$, he -DAT wait -wait -REFL

ibi bida-lugu he'd be coming with a comel, camel been sheep kiiz-PURP

watering there, wandi-nda alada-na bida-lugu. wait -REFL ready-ENPH ki iz-PURP.

11-12. (Told in English.)

13. anda diga -nda manager nani-ligu awada nani-ga I retur-PRES see -PURP there see -PAST

"Old felzow's done, gulba widji -nda."

sick become-PंRES." 
14. aṇi yuga-nḍa mani-na-diga -lugu, Maṇbi-rigu

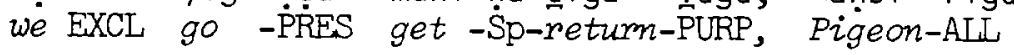

digi -ligu uga-na.

take back-PURP he - $\overrightarrow{\mathrm{A} C \mathrm{C}}$.

15. "Which way you want to go" uga-na yambaga-na. he -ACC ask -PRES.

"AdeZaide." AdeZaidi-rigu, danga-lugu gananada. -AIL, sit -PURP there.

16. minbaru nañi-na, gananada wandja-da. doctor see-PRES, there die -PRES.

17. ilina gari-ri gudni-nda, uga i! ina warbi-nanga -da thus they-ERG put-PRES, he thus lie -CONT S-PRES

muyu-wanga-na undu nani-ligu muyu widni-nura, sun-rise-IOC you ERG see -PURP sun set -CONT,

didna gudnangari, gaḍabu didnangara. foot south, head north.

18. unba yuga-ga Farina cemetry gari-na gananada you go -PAST they-ÂCC there

nani-ligu il ina anari anari nani-gura Mrs Mahomet, see-PURP thus this way this way see -ANC

a! uwa uga-guna, $M \bar{u} s \bar{a}$, all north-south, at Marree too. child she-POS

\section{Translation}

1) The old man was staying on Murnpeowie; he used to cart things driving camels to Kanowana, driving them on to Innamincka, and travelling by camel along the Cooper down this way, to Marree, and then up again to Nappa Merry station (all over) Yawarawarga and Yandruwanda country.

2) You know the explorers Burke and them, they died there (near Nappa Merry). They went back there and they didn't have any food at all. The Aborigines were getting them some and used to bring some for them; they (Burke and the others) died very close to that place (Nappa Merry). That old man. (who used to take camels up to Nappa Merry) he was really ancient.

3) He had been travelling about everywhere, but now he had come back to stay on Murnpeowie, he just sat there, and his camels just walked around, yes! He had become a sick man. He had seven camels.

4) Then I came there as I was travelling around (working on the netting fence). I was a grown man then. He wasn't working, he was just sitting there, doing nothing.

5) He had come back and he had been taken ill, the old Afghan. He was there all alone. I came there to Mulligan Spring, on Murnpeowie. 
6) He used to go to Murnpeowie Station to collect supplies of food and then come back to stay (near the Mulligan Spring). I went from the (dingo) fence to see him.

7) I saw him lying there, and he spoke like this: 'Oh me, I thought I'd die, got nothing to eat! Me sit down here'.

8) He sat there, waiting for cockatoos to come 'cocky come, me get'm gun, we want'm two, brother', (he was waiting there) to kill and cook two cockatoos.

9) I spoke like this 'There are sheep around Gunuwanda Spring, they are coming back there all the time'. 'Which way you come? Water in spring?' 'I came that way, and I had a drink of water (from the spring)'.

10) 'Ah, me go!' I went and waited and waited for him so that we could kill a sheep, he was going to come with a camel - his camels had been drinking there (at the spring), I was waiting ready to kill a sheep.

11) 'Me shoot'm cut' $m$ throat and you carry the meat, I'll have plenty now', he said, 'but no, Sayyid (a Syrian hawker) didn't come, cut'm throat' - they pray when they cut'm throat, Afghan way.

12) (So he started saying): 'Me eat'm if you cut'm throat you say same as me Bisamala wala akuba

[i.e. Bismallāh wallahu Akbar 'in the name of Allāh who is great'].

'All right, but you'd better kill for yourself after this when I'm not here', I said.

13) I went to see the manager (at Murnpeowie station); I saw him there and said: 'That old fellow is done for, he's become very sick'.

14) We went to get him, to bring him back to Murnpeowie station.

15) 'Which way do you want to go?', the manager asked him. 'Adelaide', he said. He went to Adelaide to stay there.

16) He saw the doctors there, and he died there.

17) They put them into the grave like this, they lie like this, that from the sunrise side they look towards the sunset; their feet are to the south, their head to the north. ${ }^{14}$

18) You've been to Farina cemetery, you've seen them there lying this way, you've seen them, Mrs Mahomet and her children, and Mūsā, all northsouth, and at Marree too.

\section{Comments on the customs of the Afghans}

\section{a) Mona Merrick and Arthur Warren}

The following remarks were made at various stages in conversations with Mona Merrick and her brother Arthur Warren. These remarks reflect what were considered the most interesting features of the behaviour of Afghans. Frequent topics of conversation were food, money and the cruel practice of over-loading camels.

14. 'The graves of the Muhammadans are so dug as to allow the body to lie with its face towards Mecca, consequently in India they were dug from north to south'(Hughes 1935, s.v. 'graves'). It is interesting to note that the Afghans simply carried on this Indian tradition in Australia and did not adapt it in the southern hemisphere so that the body should face Mecca. 


\section{ABORIGINAL HISTORY 1981 5:1}

1. They used to eat chopatty. Then we start eat chapatty. maga baṇda maba-nda, maga-bi!a nuga, waya nigi fire big make- , fire-coal much, wire there gudni-nda walgarara a!̣ damper wadni-nda. Abigana-ru put -PRES light very cook-PंER. Afghan-ERG junda-ga show -PAST.

2. gari curry wadni-nda, curry waru -nana madlandi, they cook- $\dot{\mathrm{P} E S}$, long ago-EL bad, maga-buru maṇa -daga $-1 i$, da! $i$ burda-burda- 1 i. fire-having mouth-pierce-HAB, tongue bite-bite-ḦAB.

3. Abigana maldja danda bagu -ru guni-1i, SaZaam Afghan not things empty-ABL give- $\overrightarrow{\mathrm{H}} \mathrm{B}$ mani -gu mani mani-ligu, mani-gu wadlara. money-DAT money get -PURP, money-DAT hungry.

4. mani namba-ga gari-ri, walgi-nda-ya-nu

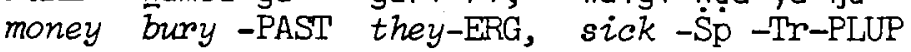

gambabina banḍa-na, gambabina shuta-ma-nda, dugulu

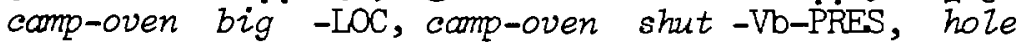

baga-ṇa-1ugu namba-ḍa-1ugu. aṇandara $d \dot{i g}-\dot{S} \dot{p}-\dot{H} I S T$ bury-Sip-HIST. we mother and us chizdren badni nañi-ga waba-nda-na. nothing see -PAST hunt-Sí -NP.

5. gari-guna nuba maldja nigi danga-nura, gari mani-jura they-POS wife not here stay-CONT, they take-CONT

niginda wadlu -nana ulju!a ulju!a waru ulju!a here country-EL woman, woman white woman

waga mani-nda.

black take-PंRES.

6. bundju gari-ri wadili bida-nda, ungu djindja-da meat they-ERG own kiiz-PंRES, throat cut -PRES

Abigana-ru undu bida-nda gari-ri maldja dani-ra, Afghan-ERG you ERG kizz-PRES they-ERG not eat-PUNC, gari-ri ungu djindja-da nannygoata, budluga, they-ERG throat cut -PRES bulzock rabbiti, mulabara gudna-djildi gari-ri ungu rock pigeon, waterhen they-ERG throat djindja-da: they didn't worry about fish, they got their cut -PRES:

throats out anyhow! Ha! 


\section{AFGHAN STORIES}

7. yaguda bargulu bargulu gudni-nda gamulu mudlu-wa!bu-na, bag two two put -PRES camel back-bone-LOC,

gamulu badni wạ̣i -nda luda-ru baṇda-ru

come 2 nothing stand-PंRंES Zoad-INST great-INST

darba-agura.

crush-ANC.

b) Comments by Ben Murray.

Because of their itinerant lifestyle many of the Afghans took their personal responsibilities lightly and some completely ignored their part-Aboriginal children. This is brought home by Ben Murray.

1. anduna anja Bejah, i! ina gari: never look after us my father thus they:

when we were young, bagu aṇi danga-ga.
empty we EXCL sit -PAST.

2. uga malga Mar̄iri-na, roada-na gada -libana,

he not Marree -LOC, -LOC travez-ÂNC,

undu jurga-ra uga-guna story, Northern Territory,

you ERG know -PUNC he -POS

Mt Isa gari yuga-nda.

they go -PRES.

3. dadlu gari yuga-nda : Jack Bejah, I call'm brother, empty they go -ṔRES

uga yuga-nda diga -lugu, wandja-diga -lugu,

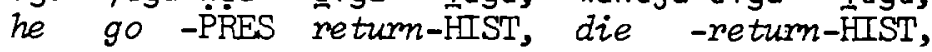

dropped dead on the Marree racecourse. I was already

working camel when he, my father, got married ... (to a part Afghan woman).

4. gari-ri namba-na Farina-na dugulu baga-na dint, they-ERG bury-PAST Farina-Loc hole dig-PRES tin,

milk-tin, coffee tin gudni-nda waya -gi -di! put -P̈RES night-EMPH-EMPH!

madabuda Mariri-na that old Khan madabuda-ru

old̄ man Marree-LOC old man -ERG

namba-ga i! ina nayi toilet, washing clothes line, bury -PAST thus here

fence-post gananaḍa namba-ga: "Con't keep'm in my there bury-PAST:

house, everybody looking" guldji pebble(i.e. money) biğ

gold too, can't find'm now. 


\section{Translation}

a) Mona Merrick and Arthur Warren:

1) They used to eat chapatties. Then we started eating chapatties. We used to make a big fire, with a lot of hot coals, and we put some wire netting on top, and cooked some really light dough. The Afghans showed us how to do it.

2) They used to cook curry. In the olden days that curry was horrible, it burnt like fire, it cut into your mouth and it bit your tongue!

3) An Afghan will never give anything away for nothing. 'Salaam' they say for money, they want to get hold of money, they're hungry for that money.

4) They used to bury their money: if they got sick they'd put the money in a camp-oven, they shut the camp-oven, dug a hole and buried it. My mother and my brothers and sisters, we were always looking for it, but we never found any.

5) Because they didn't have their own wives with them, they took women belonging to this country, white women and black women they took.

6) They always killed their own meat; they cut the animal's throat. If you killed meat for them they wouldn't eat it. They cut the throats of goats, bullocks, rabbits, rock pigeons and even waterhens: they didn't worry about cutting the throat of fish, because they've had their throats cut anyhow, ha!

7) They usually put four bales on a camel, on its back so that the camel couldn't even stand up (unaided), it was pressed down by that enormous load.

b) Comments by Ben Murray:

1) My father was Bejah; ${ }^{15}$ that's how they were: they never looked after us when we ${ }^{16}$ were young, we had nothing.

2) He was never in Marree, he was always on the road, he travelled about, you know the story, they went to the Northern Territory, they went to $\mathrm{Mt}$ Isa.

3) But it didn't do them any good: Jack Bejah, I called him 'brother'17 he went off (with father) he came back, he came back to die; he dropped dead on the Marree racecourse, I was already working with camels when my father got married ... (to a part-Afghan woman).

4) The buried (their money) at Farina, they dug a hole and put (the money) in a tin, a (powdered) milk tin, or a coffee tin, and they put it in the hole at dead of night. An old man at Marree, that old Khan, he also buried (his money). They buried it there under toilets, clothes lines and under fence-posts: 'Can't keep it in my house, everybody looking' (the old man said). It was big money and gold too, but nobody can find it now.

15. Bejah Dervish was a most highly esteemed and deeply religious man. When he retired from camel driving he lived at Marree. He had been a member of the Calver-Wells expedition of 1896 in Western Australia and distinguished himself by saving Wells when he got lost. A photo of Bejah and a lively description of this fine old man were published by Farwell (1950).

16. Ben Murray is referring not to himself and his brothers, but also to other children of Afghan camel drivers.

17. He was a half-brother, of part European descent, who had been acknowledged by Bejah. 


\section{AFGHAN STORIES}

\section{Travelling with an Afghan camel string}

This account was given by Johnny Reece of Marree, the oldest Wanganuru man now living. He was born in about 1901 at Gudnugu, Koonakoo waterhole, on Alton Downs, in Nulubulu country: his parents had just left the Simpson Desert. He fled from the cruel conditions at Alton Downs and in about 1915 went to Andrewilla, where there was a large Aboriginal camp. They were mainly Wanganuru people who lived there, but also remnants of the Yaluyandi, Yawarawarga, Garaguru and Namani. In 1917-1918 he came down the track to Marree. He was at first frightened of the Afghans, then worked for them. He clearly remembers how hard the Afghans - and he - had to work. He describes a journey in which they averaged 35 miles a day up the Birdsville track and beyond; this was quite normal for a camel-string.

1. magidi-buru Ablgana gari, gadji-nda wadlu-ja gun -having Afghan they, turn-PंRES land -LOC bigi-bigi bardjana magidi-ri wadni-nda, anda

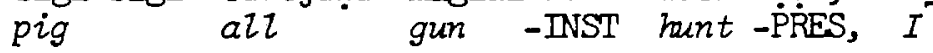
dadlara ana njug̣u wadni-lira bigi-bigi will. frightened me too hunt-POT pig like.

2. "Azim Am̄̄ra anduna mayuda; didna-ra yuga-ga, my master; foot -CAUS go -PAST,

yuga-nda luda yigi-ligu Kidmani-gu, didna-ra go - $\dot{\mathrm{P} R E S}$ Zoad shift-PURP -DAT, foot -CAUS

yuga-nda garmulu gudi-nda, jandaradana-ñda gamulu.

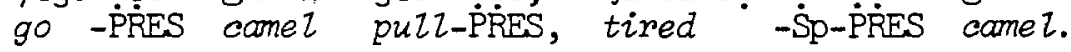

3. ani -guna jura Clayton, Claytona-ru yuga-ga Etadumna, we EXCL-POS camp -ABL go -PAST

$\begin{array}{lllll}\text { muyu nuyu-na yuga-naru Manurani } & \text { Manurani -ri } \\ \text { day one-LOC go -PLUP Mungeranie, Mungeranie-ABL }\end{array}$

Garawaḍa gudnala-ṇda awanda-gi, Garawaḍa -ru

Kirrawadinna sleep -PRES there-EMPH, Kirrawadinna-ABL

yuga-ga Wa!uru -rugu

go -PAST Mt Gason-ALL.

4. gamulu gudi-nda didna-ra Gandirida-rugu yuga-ga puzz-PRES foot-CAUS Gandirida-ALL go -PAST

Gandirida-ru Nalarawili-rigu muyu nuyu-na gudnala-nda Gandirida-ABL Andrewizla-ALL day one-LOC sleep -PंRES

yuga-nda -gi wana-wana Digiri -rigu, yuga-lugu

go-PRES-EMPH early Dickeree-ALL, go -HIST

Digiri -ri Wir̆ari rigu

Dickeree-ABL Birdsvizze-AIL. 
5. muyu gudnala-nda, anda malga narabila-nda day sleep -PंRES, I not rest -PंRES Dandabidi-rigu Dandabidi-ri Duri -rigu, awanda-ru Blüff -ALL B̈luff -ABL Durie-ALL, there-ABL Mt Leonard.

6. ga!a wandila-nda wadlu warida -rugu Monkira-rugu. creek folzow-PंRES country distant-ALI -AIL.

gamulu-pa diga -nda nigi Mariri-rigu danga-da

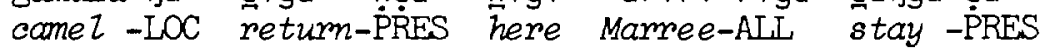

niginda.

hereabouts.

7. anda juyu, bargulu Abigana, mayuda, dirga-guna, bula I one, two Afghan, master, oven-POS, two

yuga-nd̦a, bula wanba-d̦a

go - $\dot{\mathrm{P}} \mathrm{R} E S$, two ride-PंRES.

8. adu wad -ma-nda gari-na madli-ma-nda

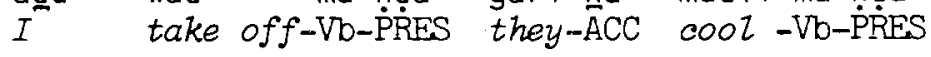

mudlu-wa!bu, gari madli-na juba-na-nda gari back-bone, they cool-LOC lie-S̈p-PंRES, they marga-nda njinda dani-ra, gabulu gudni -nda

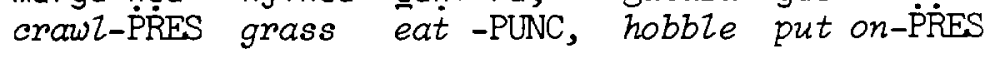

ildingildinga gudni -nda nawi-na irdja-irdja-ra bezz

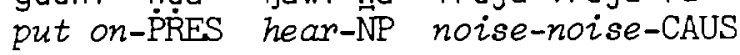

yuga-pura.

go -CONT.

9. gulbari-1i dani-nda curry, gudnala muyu widni-jura three -ADV eat - $\dot{\mathrm{P}} \mathrm{R} E S$ sleep sum set -CONT wana $-1 i$ wanga-na, yuga-nda gura-1i, malga

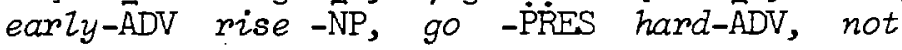
narabili-na niginda narabili-na, fifty camel, loading rest $-\mathrm{NP}$ hereabouts rest $-\mathrm{N} \mathrm{P}$

Kidman stores.

10. Camel get away from us too, gamulu gari dada-na comel they send-PRES

Wa! uru -ru yuga-nda ani yuga-nda azz day,

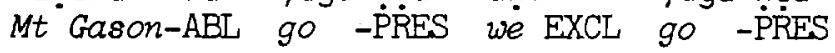
narga -na digi -na, uga yani-nda: gamulu evening-LOC take back-NP, he say-PंRES:

uga yuga-nda warida-rugu malg' anda prayer he go -PंRES far -ALL not I

widi -rinaru.

become-PLUP. 


\section{Translation}

1) The Afghans always carried guns, they travelled around the country shooting down all the pigs, I was scared in case they shot me down too like a pig.

2) 'Azim Amir was my first boss. I went on foot, taking a load up for Kidman. ${ }^{18}$ I walked and walked leading the camels, but when I got tired I rode on a camel for a while.

3) Our (first) overnight camp (out from Marree) was Clayton. From Clayton we went to Etadunna in one day and then went to Mungeranie. From Mungeranie we went to Kirrawadinna waterhold. We slept there overnight and went on to Mt Gason.

4) I led the camels, travelling on foot, and we went to Gandirida waterhole (just 4 miles on from Clifton Hills), and from Gandirida waterhole we went to Andrewilla. We slept there for one night and setting off early we went to Dickeree waterhole (near Pandie Pandie). We went on from Dickeree waterhole to Birdsville.

5) We slept there for one night, I never had a chance to have a bit of a rest there. We went to the Bluff (now Rosebeth Station), from the Bluff to $\mathrm{Mt}$ Leonard.

6) We followed the creek, the Diamantina to that distant land, to Monkira. We then came back by camel to Marree and stayed around here.

7) I was on my own, and there were two Afghans, the boss and the 'oven-man' (the cook). They both walked and rode (at intervals).

8) I was the one who took off the loads and let those camels cool down their backs. They lay around in the cool of the evening, they moved about slowly eating grass. I put hobbles on them and I put bells on them so that we could hear the noise of them moving about.

9) The three of us then ate curry and went to sleep as the sun set, so as to rise at first dawn. We went all in one go, we were not to have a chance to rest anywhere on the way, we only had a rest when we got back here to Marree. We had fifty camels, laden with Kidman's stores.

10) A camel got away from us too. They had let the camel go at Mt Gason. We went all day looking for it and got it back at night time. He ('Azim Amir) said: 'That camel went a long way off because (that night) I hadn't said my prayers'.

\section{Syrian Traders}

Muslim and Christian traders ${ }^{19}$ from 'Syria', i.e. Syria and Lebanon, came to the north of South Australia much later then the Afghan camel drivers. Most of them came in the first decades of the present century, particularly before World War I, in order to escape from Turkish oppression. They were classified as 'Abigana' by Arabana people who were nevertheless well aware of

18. Sir Sydney Kidman (1857-1935) was a major owner of pastoral properties, particularly in central Australia (see Idriess 1935).

19. From various comments made it appears that the cruel Syrian and Sayyid Ali were both Muhammadans, while Mansoor was a Christian. 


\section{ABORIGINAL HISTORY 1981 5:1}

the difference between these new 'Abigana' and the camel drivers; it was the commercial-mindedness of these traders - greater even than the commercialmindedness of the old-style Afghans - that above all caught the attention of Arabana people. Mona Merrick and her brother Arthur Warren recalled the days in the twenties when these traders visited Finniss Springs. The traders fulfilled a valuable function: they brought 'luxury' goods that did not form part of the usual provisions.

a) The Cruel Syrian

1. Abigana wad̦u juru - jana mugaḍi guba-guba, uga yuga-ga Afghon country other-El hat little, he go -PAST Finnissi -na soap, handkerchief comb selza-ma-nda:

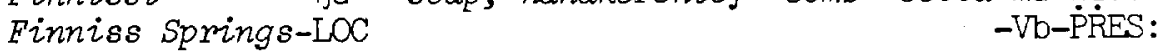

"I got nice little comb for hair-style."

2. gamulu nuyu-na uga yuga-ga. aṇi wi $\bar{r} i-g a$ came 2 one -LOC he go -PAST. we EXCL buy-PAST handkerchief, soap, comb, one shizzing.

3. gamulu-na ganjari banḍa gudni-ga, railway chain. came I-LOC chain big put -PAST

gamulu widi nuga ganjari baṇa gudi-nda didna-na.

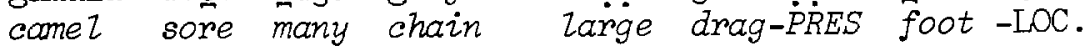

4. waga!a gamulu-gugu-na danga-agura mudlu-wa!bu-na, crow camel-back-LOC sit -ANC back-bone -LOC,

budluga njuri gugu-wari, waga!a-ru widi dani-na-na bullock skin back-cover, crow -ERG sore eat - $\bar{N} \mathrm{~F}-\mathrm{LOC}$

gamulu saddla-na widi-buru mudiu-wa!bu. camel saddle-LOC sore-having back-bone.

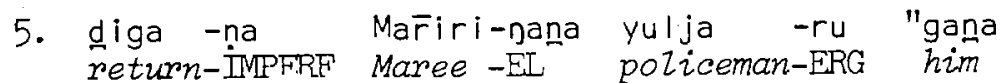

mani-ga -du galba-ra -gi "gana gamulu paru -na :

take-PAST-EMPH shut-PUNC-EMPH him camel manner-LOC:

"Cruelty to animazs!"

6. gamulu maldja bur̄a-ga yulja -ru mani-ga. camel not die-PAST policeman-ERG take-PAST.

b) Mansür.

1. Mansīr jurgu ala, danda mugadi, photo mani-ga; good very, clothes, hat, take-PAST;

anda guya galgawalda nani-ga. waru Mansūr I girl sometimes see-PAST. long ago

mugadi, njiba wir̄a-nda.

hat, dress sezz-PRES. 
AFGHAN STORIES

2. working-man danga-ga $\begin{array}{rr}\text { Bit-PAST } & \text {-LOC }\end{array}$

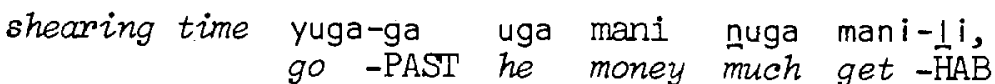

anandara njiba, mugadi, danda

we(our mother and us chizdren) dress, hat, clothes,

comb wiri-nda, anduna abidji-ri djarda wiri-ga. buy-PRES, my father-ERG shirt buy-PAST.

3. working man nuba mani badni anduna abidji-ri wife money nothing $m y$ father-ERG

njiba wiri-la -lugu.

dress buy -ALT-HIST.

4. Mansür motorcar banda, njiba nurgu.

big, dress nice.

c) Sayyid Ali.

1. Sayyid Ali had a van, two camels dragging it.

2. Sayyid Ali mani baṇa, didna-walga njiba, mugạ̣i, money big, shoe dress, hat;

danda.

clothes.

3. abidji-ri wīi-nda prints njiba mani-ri garba-na-na. father-ERG buy-PRES dress self-ERG make-NP-LOC

anandara wiri-nda almond, peanut.

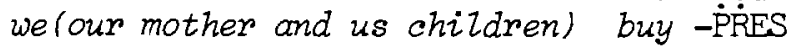

4. Abigana wadlu juru - jana, mugạ̣i guba-guba. guya Afghon country other-EI, hat little. girl

bargulu, guya nurgu.

two, girl pretty.

5. (Told in English.)

\section{Translation}

a) The Cruel Syrian

1) An Afghan from a different country (not India), wearing a small hat (a fez), he came to Finniss Springs selling soap, handkerchiefs and combs: 'I got nice little comb for hair-style' he said.

2) He came with just one camel, and we bought handkerchiefs, soap and combs, for one shilling (everything he had cost one shilling).

3) He had put an enormous heavy chain on this camel, a railway chain. The camel was covered in sores and it dragged this big chain on its foot. 
4) Crows were sitting on this camel, on its back, it had a rough bullock hide (in lieu of a saddle) and the crows were devouring the camel where its back was full of great sores from this saddle.

5) He went back to Marree and the Marree policeman took him and put him in gaol because of the camel: 'Cruelty to animals!'

6) The camel didn't die, the policeman took it (and looked after it).

b) Mansūr

1) Mansūr was a really good man, he had clothes and hats for sale and he took photos for people. I used to see him (at Finniss) occasionally when I was a little girl. It was a long time ago; Mansūr sold hats and dresses.

2) Mansūr was a working man at Beltana, but he came at shearing time (when there was plenty of money about) and he used to get a lot of money; all of us, my mother and us children bought dresses, hats, clothes and combs, and my father bought shirts.

3) If the wife of one of our working men didn't have any money, my father would buy a dress for her.

4) Mansūr had a big motor-car, and he sold pretty dresses.

c) Sayyid Ali

1) Sayyid Ali had a van, two camels dragging it.

2) Sayyid Ali had lots of money, he had shoes, dresses, hats and other clothes for sale.

3) Father used to buy prints from him so that we could make our own dresses. Mother and all of us used to buy almonds and peanuts.

4) He was an Afghan from a different country (not India), wearing a small hat (a fez). He had two daughters, pretty girls they were.

5) He'd had a wife, but she ran off, and in the end those two girls ran off too, they went and got married in Queensland.

AUSTRALIAN NATIONAL UNIVERSITY

APPENDIX 1

The Phonemes of Arabana-Wayganuru

\begin{tabular}{|c|c|c|c|c|c|c|}
\hline & labial & interdental & alveolar & retroflex & palatal & velar \\
\hline stops & $\mathrm{b}$ & $\underline{\mathrm{d}}$ & d & ḍ & $\mathrm{dj}$ & $\mathrm{g}$ \\
\hline nasals & $\mathrm{m}$ & $\underline{n}$ & $\mathrm{n}$ & n & nj & g \\
\hline laterals & & 1 & 1 & $!$ & $\mathrm{lj}$ & \\
\hline vibrants & & & $\hat{r}, r$ & ! & & \\
\hline glides & $\mathbf{w}$ & & & & $y$ & \\
\hline
\end{tabular}




\section{AFGHAN STORIES}

Note

Certain nasals and laterals in Arabana-Wanganuru have pre-stopped allophones: -bm- corresponds

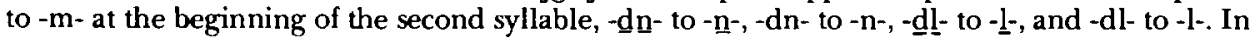
order to make the spelling approximate as closely as possible to the pronunciation these prestopped consonants have been included in the orthography.

For simplicity the cluster -njdj- has been written -ndj-.

\section{APPENDIX 2}

\section{List of Abbreviations}

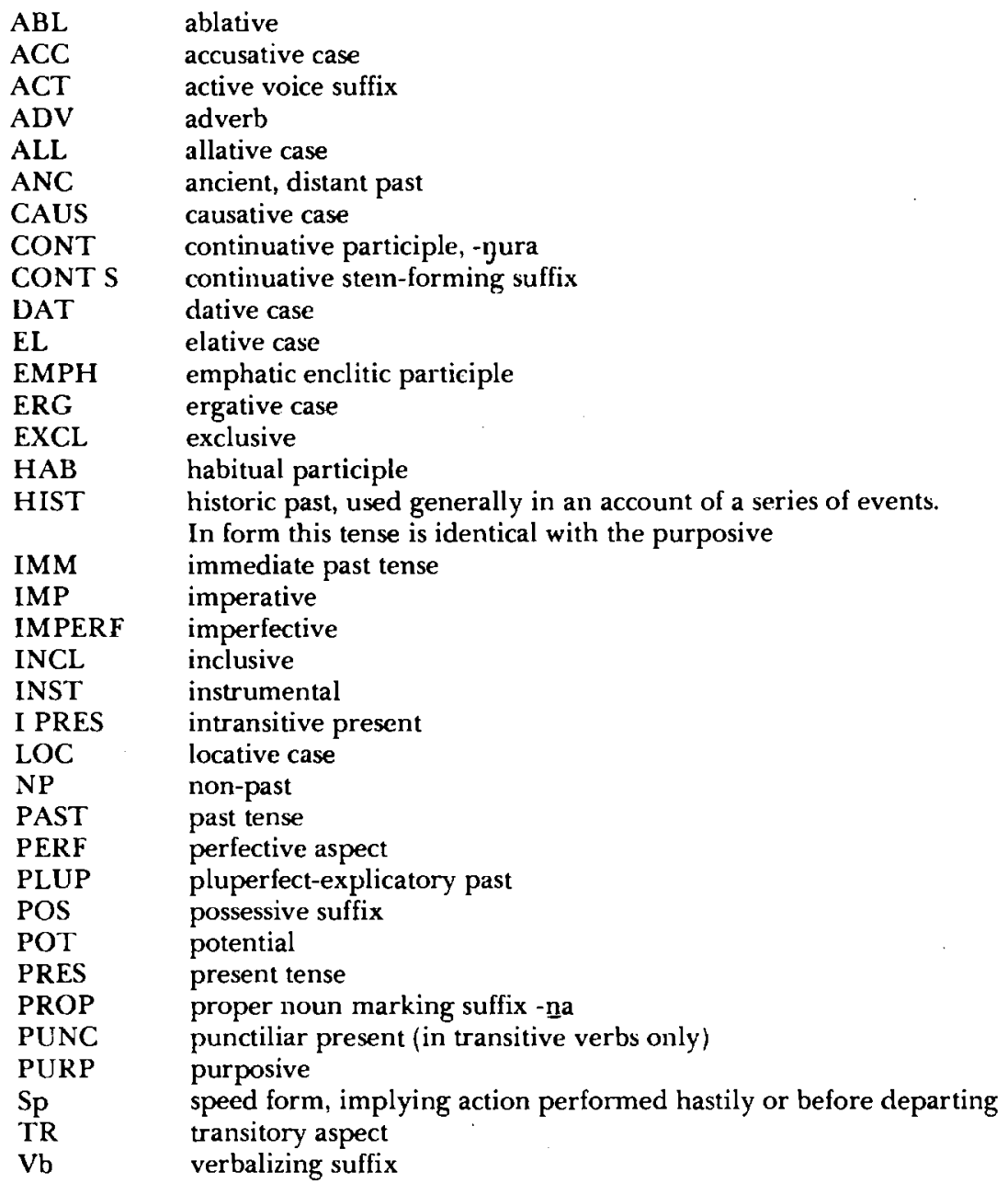

In the translation brackets are used to enclose phrases that are not in the original, but have been added by way of explanation. 


\section{ABORIGINAL HISTORY 1981 5:1}

\section{BIBLIOGRAPHY}

Austin, P.K. A grammar of Diyuri, South Australia Cambridge, 1981.

'The Afghan snake-charmer', in Hercus, Luise A. and Peter Sutton eds. This is what happened. Canberra, (forthcoming).

Barker, H.M. Camels and the outback. Melbourne, 1964.

Donaldson, Tamsin. 'Translating oral literature: Aboriginal song texts', Aboriginal History, 3(1), 1979:62-83.

Farwell, George. Land of mirage: the story of men, cattle and camels on the Birdsville track. London 1950.

Fuller, Basil. The Ghan: the story of the Alice Springs railway. Adelaide, 1975.

Hercus, Luise A. 'Arabana and Wanganuru traditions', Oceania, 42(2), 1971:94-109.

—_ 'Tales of Nadu-dagali (Rib-bone Billy)', Aboriginal History, 1(1), 1977:53-76.

— "How we danced the Mudlunga", memories of 1901 and 1902', Aboriginal History, $1(1), 1980: 5-31$.

Hughes, T.P. A dictionary of Islam. London, 1935.

Idriess, Ion L. The cattle king. Sydney, 1936.

McKnight, T.L. The camel in Australia. Melbourne, 1969.

White, Isobel M. __ 'Sexual conquest and submission in the myths of central Australia'. in Hiatt, L.R. ed. Australian Aboriginal mythology. Canberra, 1975:123-142. 